\title{
The Halal Regulatory Framework in Malaysia should be Consolidated: A Proposal ${ }^{1}$
}

\author{
Apnizan Abdullah*
}

The formation of Halal Development Corporation (HDC) in September 2006 was a strong indication of the Malaysian government's aspiration towards actualising Malaysia as the regional and international hub for Halal industry. HDC is dedicated to becoming the central implementation agency for key Halal industry development initiatives. Its pertinent roles are to promote Halal industries, liaise with government agencies and authorities and to assist business entities and investors. ${ }^{2}$ Since Halal is a national agenda, in discharging its function HDC closely works with various agencies which include Department of Islamic Development Malaysia (JAKIM), State Religious Council/Department of States, Ministry of Domestic Trade, Co-Operatives \& Consumerism (MDTCC), Ministry of Trade And Industry (MITI), Malaysia External Trade Development Corporation (MATRADE), Malaysian Industrial Development Authority (MIDA), Department of Veterinary Services, Department of Standards and many more. A fuller picture of the Halal certification procedure in Malaysia, as I attempt to show below, is in order to place my proposal for its consolidation in its proper context.

Generally, Halal matters in Malaysia are perceived by the public to be solely supervised by the Department of Islamic Development of Malaysia or Jabatan Kemajuan Islam Malaysia (JAKIM). Actually, JAKIM is one of the government entities empowered by law to govern one aspect of Halal matters, namely Halal certification procedure and Halal logos. Halal matters include the regulation of the Halal industry, Halal certification process and procedures, Halal logos, Halal standards, laboratory testing and many more. In short, Halal matters are governed by piece meal legislation. The main Act governing the Halal industry in Malaysia is the Trade Descriptions Act (TDA) 2011. Section 29 of this Act stipulates that the Minister of Domestic Trade, Cooperatives and Consumerism may, by order, require the goods or services supplied to the consumers to be certified by a competent authority or marked with a mark, determined by the Minister. This power may be exercised when it appears to the Minister that such requirement is necessary or expedient in the interest of the consumer(s). As far as the Halal certification process and logos are concerned, the power to govern these matters is vested in JAKIM and the Islamic Religious Council/Department 
or Majlis/Jabatan Agama Islam Negeri (MAIN) of each state in Malaysia (except the Federal Territories). Both JAKIM and MAIN of the various states are the legitimate bodies for the Halal certification in Malaysia bearing a specified Halal logo. This position is well recognised in the Trade Descriptions (Definition of Halal) Order 2011 and Trade Descriptions (Certification and Marking of Halal) Order 2011 which are pieces of subsidiary legislation issued by the respective Ministers under the purview of TDA 2011.

TDA 2011 repeals the Trade Descriptions Act (TDA) 1972. Under the old TDA 1972, Halal matters were mandated to the Ministry of Domestic and Consumer Affairs as stipulated in the repealed (TDA) 1972. Neither the TDA 1972 nor its by-laws, the Trade Descriptions (Use of Expression Halal) Order 1975 and Trade Descriptions (Marking of Foods) Order 1975 recognised JAKIM and MAIN of the various states as the competent authorities regulating Halal certification matters even though JAKIM was known as a body governing Halal matters. Furthermore, the Trade Descriptions (Use of expression "Halal") Order 1975 allowed individuals or private companies to issue their own certificates and Halal logos. Consequently, neither JAKIM nor MAIN could enforce any compliant pertaining to cases on the abuse of Halal logos or Halal certificates. In managing such cases, JAKIM must first notify the Ministry and every action taken must be carried out in presence of the Ministry officers. Indeed, the enactment of 2011's TDA has placed JAKIM or MAIN in the lead position in regulating Halal certification procedure and enforcement matters. This will significantly advance Halal as the national agenda of the country.

To administer its function as the Halal certification authority, JAKIM had issued the Manual Procedure for Malaysia Halal Certification 2014 (the Manual) and Guidelines on Halal Assurance Management System of Malaysia Halal Certification 2011 known as Halal Assurance System (HAS). The Manual must be read with relevant standards, Fatwa decisions and related regulations which are in force when Halal Certification is carried out.

In addition to the Manual and HAS 2011, the supervision of Halal certification procedure is supplemented by the provisions in thirteen (13) Halal standards issued by the Department of Standards Malaysia (DOSM). The power of such issuance is granted to DOSM through its governing law, the Standards of Malaysia Act 1996. The Halal Standards cover a wide-ranging agenda of Halal industries in the country, including Halal Foods and slaughtering, Halal tourism and hospitality, Halal logistics and handling process, Halal management, management systems, Halal pharmaceuticals, Halal packaging and Halal cosmetics and personal care products. It is worth noting that the very notion of standards is underlined by its voluntary attribute. Compliance with a standard is not mandatory unless it is made mandatory by the laws or the applicant opts to comply. 
Furthermore, other ministries or government agencies authorised by laws to carry out specific procedures for the purpose Halal certification process include the Ministry of Health, which is mandated to carry out and supervise certification process of the Good Manufacturing Practices (GMP) and Hazard Analysis \& Critical Control Points (HACCP), the Department of Veterinary Services (DVS) of Ministry of Agriculture which deals with meats and livestock industry especially Halal Meats and slaughtering.

In a nutshell, Halal industry in Malaysia is not governed by a central governing body under a single statute. Essentially, it involves various entities under the purview of different jurisdictions which are specified in the relevant Acts or statutes. Currently, in addition to the TDA 2011 and its by-laws, other laws and regulations governing Halal matters include Food Act 1983, Food Regulations 1985, Consumer Protection Act 1999, Food Irradiation Regulations 2011, Road Transport Act 1987, Customs Act 1967, Customs Order (Prohibition of Imports) 1988, Wild Life Protection Act 1972, Animal (Importation Order) 1962 and a myriad of guidelines and manuals issued by relevant authorities.

One more step towards standardisation of Halal national agenda was the announcement made by the Deputy Prime Minister, Ahmad Zahid Hamidi on February 11, 2016 on the establishment of Majlis Halal Malaysia (MHM) or Malaysia Halal Council has marked another milestone in the quest to actualise the Halal industry under a centralised regulatory environment. He was reported to have mentioned that matters related to the development of Halal industry in the country will be supervised by JAKIM and HDC. Under this new initiative, JAKIM will focus on matters related to Halal certification, governance and other Shariah matters while HDC will concentrate on the development of the industry and its internationalisation. Other government agencies or entities that currently work closely with the two bodies will continue their participation and contributions in Halal related matters under the MHM. To facilitate the establishment of the MHM, a specific statute governing this entity will be prepared by MITI and JAKIM and scrutinised by the Attorney General Chamber. The proposed Act will be eventually tabled in Parliament. ${ }^{3}$

\section{JAKIM as the Sole Authority: A Proposal}

As discussed, JAKIM and MAIN of each state in Malaysia (except Federal Territories) are equally authorised to handle Halal certification procedure under Section 29 of TDA 2011 and its two by-laws related to Halal certification process and logos. With such statutory power, JAKIM has come out with the Manual $^{4}$ and $\mathrm{HAS}^{5}$ that need to be read with other relevant standards, fatwa decisions and related regulations that are for the time being in force as provided 
in Paragraph 1.2 of the Manual. Since JAKIM and MAIN are both empowered by the TDA 2011 to govern the Halal certification process, fatwas issued by the National Fatwa Committee (NFC) and Muftis from various states are equally applicable. It is important note, as already mentioned, that fatwa is a matter within the state's power. Due to this, there will be a possibility of having inconsistent fatwas issued by various states and the NFC in matters related to Halal certification process.

It is therefore proposed that the Trade Descriptions (Definition of Halal) Order 2011 and Trade Descriptions (Certification and Marking of Halal) Order 2011 should be amended to make JAKIM the sole authority for Halal certification procedure and logos. However, the proposed amendment should empower JAKIM to collaborate with MAIN of all states in discharging its function and in dealing with the above mentioned matter. With this proposed amendment to the two by-laws issued under the purview of TDA 2011, possible inconsistencies in fatwas or the Halal certification procedure could be eliminated. Additionally, the proposed amendment could assist the Malaysian government to take another step towards bringing about a centralised regulatory framework for its Halal industry that would be free of internal jurisdictional issues that could possibly dampen its trajectory of progress.

\section{Notes}

* Apnizan Abdullah is Research Fellow at IAIS Malaysia (Email: apnizan@iais. org.my).

1. This viewpoint is an enhanced work from a short article written by the author in IAIS Malaysia Bulletin (July-August, 2016).

2. Refer < <http://www.hdcglobal.com/publisher/gwm_why_hdc\#sthash. fVMYH0CM.dpuf $>$ (accessed August 28, 2016).

3. Refer $<\mathrm{http}: / / \mathrm{www} . h m e t r o . c o m . m y / n o d e / 114202>$, (accessed August 28, 2016).

4. The Manual Procedure for Malaysia Halal Certification 2014.

5. Halal Assurance System 2011 that came into force in 2014. 